\title{
HISTORIA DE LOS CEMENTERIOS DE LIMA Y EL CALLAO
}

\section{Santiago Tácunan Bonifacio* Universidad Católica Sedes Sapientiae}

Resumen: La presente investigación intenta analizar el tema de la muerte en las épocas colonial y republicana. La información histórica está sustentada en una serie de ensayos bibliográficos y fuentes documentales éditas e inéditas de diversos repositorios limeños. Completa el estudio un registro de campo que selecciona una serie de imágenes fotográficas de cada uno de los cementerios de ambas épocas.

Palabras clave: muerte, cementerios, época colonial, época republicana,

Aвstract: The present research attempts to analyze the issue of death in the colonial and republican epochs. The historical information is based on a series of bibliographic essays and published and unpublished documented sources from different repositories in Lima. The research is completed with an on-the-field register that collects a series of photographs from the cemeteries of both epochs.

KEY wOrDs: death, cemeteries, colonial age, republican age

Santiago Tácunan Bonifacio es Licenciado en Historia por la Universidad Nacional Mayor de San Marcos (2000), posee un diploma en Gestión Municipal de los Proyectos Sociales (2006) de la Escuela Mayor de Gestión Municipal. Es investigador del Seminario de Historia Rural Andina desde 1998 y de la Facultad de Educación y Humanidades de la Universidad Católica Sedes Sapientiae desde el 2006, en donde también ejerce la docencia. 
a muerte, es sin duda, un hecho social del cual se conoce poco, en vista que nos ocupamos más del cuerpo que de la muerte misma. La

muerte de manera paradójica nace con la vida, pues toda persona tiene en algún momento que morir.

Todos de alguna manera tienen miedo a la muerte, aunque para algunos cuando se llega a una edad avanzada o luego de haber vivido lo suficiente, la muerte es recibida de manera personal con beneplácito debido al descanso intrínseco que trae consigo. Por lo tanto, la muerte es más dolorosa para los familiares, pues son ellos quienes deben afrontar los ritos funerales y la pena de haber perdido a uno de sus integrantes.

El presente estudio intenta describir la historia de los principales cementerios de Lima y el Callao, fundados durante la época colonial y republicana. Anteceden a cada acápite un breve comentario acerca de la muerte durante cada una de esas épocas.

\section{EL PANTEÓN GENERAL DE LIMA O PRESBÍTERO MATÍAS}

\section{MAESTRO}

Desde finales del siglo XVIII y durante las primeras décadas del siglo XIX, el gobierno español intentó mejorar la salubridad de Lima, toda vez que esta ciudad contaba con un sistema de abastecimiento de agua precario, desagüe que corrían por medio de las calles, así como inadecuados hábitos de higiene por parte de la población que iba en aumento como por ejemplo: arrojar en forma discriminada basura y demás desperdicios en lugares circundantes a las acequias construidas a tajo abierto y en horarios inapropiados. ${ }^{1}$

1 Durante los primeros años de vida colonial los vecinos de Lima obtenían agua del río Rímac. A mediados del siglo XVI, las autoridades se preocuparon seriamente en el abastecimiento debido a las pestes y enfermedades endémicas que tuvieron que enfrentar los médicos, 
Fue el gobierno del virrey José Fernando de Abascal y Sousa (1806-1816), a pesar de la crítica situación económica y política por la que atravesaba la administración española, quien asumió algunos de los planteamientos de Unanue (1755-1833), quien inspirado en los avances de la ciencia ilustrada propuso una serie de proyectos a favor de la ciudad y la población residente en ella. Así se creó la cátedra de Botánica (1787) en San Marcos, el Anfiteatro Anatómico (1792) y años más adelante el Colegio de Medicina de San Fernando (1809). ${ }^{2}$ En esta línea de trabajo, ordenó también construir un Panteón General en 1804, tratando de contrarrestar las emanaciones de las iglesias, tal como lo manifiesta Phillipe Aries:

[...] La acumulación in situ de muertos en las iglesias o en los pequeños patios de las iglesias llegó a ser intolerable, al menos para las mentes «ilustradas» de los años 1760. Lo que ya duraba desde hacía casi un milenio sin suscitar reserva alguna, dejaba de ser soportable y se volvía objeto de vehemencias críticas. Toda una literatura lo certifica. Por una parte la salud pública se veía comprometida por las emanaciones pestilentes y los hedores infectos procedentes de las fosas. Por otra, el suelo de las iglesias, la tierra saturada de cadáveres de los cementerios y la exhibición

quienes manifestaban que las causas de estos males radicaban en la mala calidad del agua. La situación empeoró con el incremento de la población y el irregular caudal del río. Bajo estas circunstancias, el Virrey Conde de la Nieva ordenó al Cabildo de Lima ubicar manantiales de agua para abastecer a la ciudad. Luego de varios días de búsqueda, los comisionados lograron divisar un manantial a 4 millas en el valle de Ate. Para transportar el agua se construyó un edificio de mampostería para cubrir el manantial, construcción a la que se le denominó «Caja de Agua». De ella y mediante un acueducto era trasladada el agua a las principales piletas y pilas de las plazas públicas, así como a los conventos e iglesias (Cf. Tácunan 1994: 119-129).

2 El antecedentes más antiguo de la construcción de un cementerio a extramuros ocurrió en Ate (1790), Tarma (1789-1790) y en la zona rural de Arequipa (1793-1798). En Lima se tiene referencia acerca de la construcción del Cementerio del Convento de San Francisco (1803) fuera de los muros eclesiásticos (Cf. Ramón 2003: 29-35). 
de osarios violaban constantemente la dignidad de los muertos. Se echaba en cara a la iglesia que hubiera hecho todo lo posible por el alma y nada por el cuerpo, y que cobraba el dinero de las misas sin piedad por los muertos, confirmada por los restos de sus tumbas, por la elocuencia de su epigrafía funeraria. Los muertos tenían que dejar de envenenar a los vivos, y los vivos tenían que implantar un verdadero culto laico que manifestara su veneración a los muertos. Sus tumbas se convertían en el signo de su presencia más allá de la muerte [...]. (Aries 2000: 48)

Los orígenes del Panteón General se remontan a un Decreto Real emitido el 9 de diciembre de 1786 que ordenó la construcción de dos cementerios en las afueras de Lima. Esta disposición reiterada hasta en cuatro oportunidades durante 1804, se incumplió debido a la fuerte resistencia de la alta sociedad, quienes con algunos pretextos de superstición, aunque más de vanidad y egoísmo, se opusieron al cambio de la tradicional forma de inhumar los cadáveres. Su principal interés fue no perder su derecho de enterrarse en las iglesias, lugar en habían reservado espacios mortuorios individuales y/o familiares.

Tratando de mantener este privilegio, la elite limeña promovió una corriente de opinión en el pueblo relacionada a que una tumba en la iglesia era una puerta abierta al cielo. Los frailes también fomentaron esta idea de manera fervorosa, toda vez que el pago por una tumba significaba recursos para mantener los gastos religiosos.

A pesar de ello, la idea de construir un nuevo panteón se concretó luego de varios intentos frustrados y después de realizar varias actividades públicas y administrativas, a saber: corrida de toros, venta de nichos, creación de impuestos, solicitud de donaciones pecuniarias y una hipoteca sobre el terreno elegido. 
HISTORIA DE LOS CEMENTERIOS DE LIMA Y EL CALLAO

Cuadro 1. Costo del Panteón de Lima (1820) ${ }^{3}$

\begin{tabular}{|l|r|}
\hline \multicolumn{1}{|c|}{ Actividades } & \multicolumn{1}{|c|}{ Dinero } \\
\hline $\begin{array}{l}\text { Cuatro corridas de toros en la plaza mayor } \\
\text { organizada por el Cabildo de Lima. }\end{array}$ & 17.699 pesos 4 reales \\
\hline Donativos de varios Gobernadores Provinciales & 3.653 pesos \\
\hline $\begin{array}{l}\text { De varios principales impuestos a censo, sobre la } \\
\text { misma obra. }\end{array}$ & 10.500 \\
\hline $\begin{array}{l}\text { Impuestos a varias Obras Pías a 3.5\% en virtud } \\
\text { del 15\% que obtuve y cuyo Patronato dejé a la } \\
\text { Archicofradía de Nuestra Señora del Rosario }\end{array}$ & 21.352 pesos 7 3/4 reales \\
\hline $\begin{array}{l}\text { Que impuso el Dr. Matías Querejaru por un } \\
\text { aniversario }\end{array}$ & 12.000 pesos \\
\hline $\begin{array}{l}\text { Que impuso la Sra. Rosa Catalina Basques para 3 } \\
\text { Capellanías }\end{array}$ & 6.000 pesos \\
\hline $\begin{array}{l}\text { Que impuso el Dr. Buenaventura Tagle por un } \\
\text { aniversario }\end{array}$ & \\
\hline $\begin{array}{l}\text { Impuestos al 3.5\% que reconocen el rédito anual } \\
\text { de 2397 pesos 4 reales, más el canon del terreno } \\
\text { que son 78 pesos que componen la pensión de } \\
2475 \text { pesos 4 reales }\end{array}$ & 68.500 pesos \\
\hline
\end{tabular}

El arquitecto de tan importante obra fue Matías Maestro Alegría, quien inspirado en ideas neoclásicas y de ilustración, terminó de elaborar los planos en 1807. Matías Maestro nació en Vitoria (Alava) el 22 de febrero de 1766 y sus padres fueron José Maestro y Antonia Alegría Chilcano. Realizó estudios de derecho, arquitectura y pintura, licenciándose en leyes antes de arribar al Perú durante la última década del siglo XVIII.

3 En este recuento elaborado por Matías Maestro no se menciona el importe de 283 nichos y 5 osarios que equivalían a 3891 pesos. Noticia de la erección del Cementerio General de Lima. AML. N. 43 Cementerio General, año 1808-1822, fol. 1. Ver también: Odriozola, Manuel de. Documentos Históricos del Perú, p. 74. 
En Lima se dedicó a diversas actividades comerciales para luego ejercer labores clericales por recomendación de Juan Domingo Gonzáles de la Reguera, Arzobispo de Lima.

Luego de algunos años de estudio se ordenó de sacerdote secular en 1792 y continuó dedicándose a refaccionar y decorar diversas iglesias y templos limeños. Entre sus principales obras pictóricas y arquitectónicas pueden mencionarse las siguientes:

- Retrato del Arzobispo de Lima, Juan Domingo Gonzáles de la Reguera.

- Cuadro de Santa Rosa de Lima y los Santos Patrones.

- Plano de la localidad de Huarochirí (1788).

- Altar Mayor de la Catedral de Lima.

- Altar de las iglesias de San Francisco, San Pedro, La Merced, La Soledad, Capilla de Nuestra Señora de la "O", Trinitarias, Mercedarias y Santo Cristo.

- Refacción de la Catedral de Lima y la iglesia de Santo Domingo (1799).

- Construcción de la Casa de Ejercicios de Santa Rosa.

- Edificación de la capilla del Seminario de Santo Toribio.

- Diseño de la torre de la Parroquia de San Lázaro.

Maestro fue también uno de los vecinos que firmó el Acta de Independencia en 1821, miembro de la Comisión para crear un banco emisor de papel moneda (1821), miembro de la Sociedad Patriótica (1822) y Director General de la Beneficencia de Lima entre 1826 y 1835.

En 1808 se culminó el Panteón y la inauguración estuvo a cargo del virrey Abascal el 31 de mayo de ese mismo año con la exhumación de los restos del Arzobispo de Lima, Juan Domingo Gonzáles de la Reguera, 
quien había sido enterrado en 1805 en la cripta de la Catedral de Lima. ${ }^{4} \mathrm{Su}$ ataúd fue sacado de la Catedral por seis sacerdotes, quienes en todo momento estuvieron acompañados por los miembros del Clero Secular y Seglar.

La remoción de los restos del Arzobispo de Lima obedeció a que la población se mostraba reticente a enterrar a sus muertos en un espacio alejado de los altares de las iglesias y fuera de la ciudad. Las manifestaciones de protesta y desobediencia no fueron públicas, pues nadie quería contrariar las normas impuestas por la Iglesia Católica. En este sentido, la resistencia fue más bien informal y subterránea.

La bendición de la obra estuvo a cargo del Arzobispo Bartolomé María de las Heras, quien en una extensa Carta Pastoral exhortaba a los prelados a concientizar a la población para que la usen por razones de decoro y hermosura de los templos, así como por el mejoramiento de la salud pública:

No solo se han empleado las consideraciones espirituales y divinas, que ofrece el verdadero carácter de una cosa del Señor, donde solo debe percivirse la suavidad de los inciensos y aromas ofrecidos, y no el ambiente fétido de los cadáveres, sino tambien las temporales, y humanas de la salud pública. Se ha advertido, que un aire cargado de emanaciones cadavéricas, lleva la semilla, y fermento de todas las fiebres pútridas, y enfermedades malignas. Que introducido por la respiracion en los pulmones, que son la parte más susceptibles de toda impresion morbifica, es apto para propinar la muerte, y no para conservar la vida. Y que por tanto, se convierte en temible y odiosa la grata y útil mansion en los templos. Si los muebles, y

4 En 1808 también se inauguró la Portada de Maravillas —una de las más hermosas de Lima- para dotar de una salida decorosa a los cortejos fúnebres y a los familiares del occiso. El nombre de la portada fue adquirido de la parroquia contigua del mismo nombre. 
alhajas por el contacto de un cuerpo enfermo, ocasionan un uso peligroso y acaso mortal; ¿qual no inducirá un aire conductor de las exalaciones del cuerpo corrompido? Los sabios físicos del siglo contrahidos á esclarecer esta verdad, ministran un crecido número de estragos, y sucesos espantosos que han ocasionado las aperturas de los sepulcros.

[...] Esta capital veneradora de sus Soberanos, dotada de superiores luces, y posehida de la verdadera devocion, con muy poco esfuerzo depondrá las preocupaciones conservadoras aciagas de la perniciosa práctica, en que ha vivido, y comprehenderá fácilmente, que la piedad y devocion para con los santos que la estimulan á anhelar las sepulturas en las iglesias, léjos de disminuirse, ántes se aumentan abdicando los fieles esa práctica por reverencia á los mismos santos, y por restituir á sus templos la pureza, y hermosura, que les usurpa el fetor de los cadáveres. Se convencerá de la dignidad, y excelencia de los Cementerios, santificados por la iglesia para sepultura de sus hijos con especiales bendiciones, por las que se pide al Señor, que aquel lugar sea consagrado; que conceda a los difuntos, que allí estuvieren el reposo, y descanso eterno: que los libre de las incursiones de los espíritus malos; que en el dia terrible del juicio general les dé una resurreccion gloriosa.

[...] Espero en nuestro Pueblo ilustrado y virtuoso, se conveza pronta, y generalmente de las verdades propuestas, advirtiendo, que el movil del nuevo establecimiento es por una parte la reverencia, decoro, y hermosura de los templos, y por otra la salud pública; en una palabra la religion, y el Estado. ${ }^{5}$

5 Discurso que dirige a su Rey el Ilustrísimo Señor Doctor Don Bartolomé María de Heras, dignisimo Arzobispo de esta metrópoli con motivo de la apertura y bendición solemne del 
De acuerdo con el estudio realizado por Diana Aguirre acerca del Presbítero Maestro, tres fueron las razones principales utilizadas por la ilustración para fomentar la construcción de un cementerio fuera de Lima:

- La contaminación del aire producido por la descomposición de los cuerpos.

- El origen e instauración de los cementerios a través de la historia.

- Por orden moral, pues se consideró indecente ensuciar los templos e iglesias con cuerpos putrefactos. (Cf. Aguirre 2005: 7- 8.)

El Panteón General, llamado también «Cementerio General» durante sus primeros años de funcionamiento, estaba ubicado en una zona apartada al noreste de Lima y fuera de las murallas que la circundaban. ${ }^{6}$ Su elección obedeció a consideraciones geofísicas, pues los vientos soplan en forma ligera de este a oste evitando con ello la contaminación de la ciudad con las emanaciones de los cadáveres.

Según Hilda Barentzen (2006: 14-15), el proyecto original de Matías Maestro contó con una capilla a la entrada del Panteón (hoy puerta cuatro), la cual existió por lo menos hasta finales del siglo XIX, tal como lo evidencia la imagen aparecida en el libro de Manuel Atanasio Fuentes (Cf. Fuentes 1867: 57).

Cementerio General erigido en esta capital. AML. N. 43 Cementerio General, año 18081822, fol. 1-14. Se ha mantenido la ortografía original.

6 El terreno perteneció al Hospital de Santa Ana, aunque también se menciona que las obras se dieron inicio el 20 de abril de 1803 en el terreno adquirido a Juan Miguel de Castañeda de una extensión de 2 fanegadas y 33 almudes. El costo total del área fue de 2602 pesos 4 3/4 reales, los mismos que fueron reconocidos al 3\%. Noticia de la erección del Cementerio General de Lima. AML. N. 43 Cementerio General, año 1808-1822, fol. 1 . 


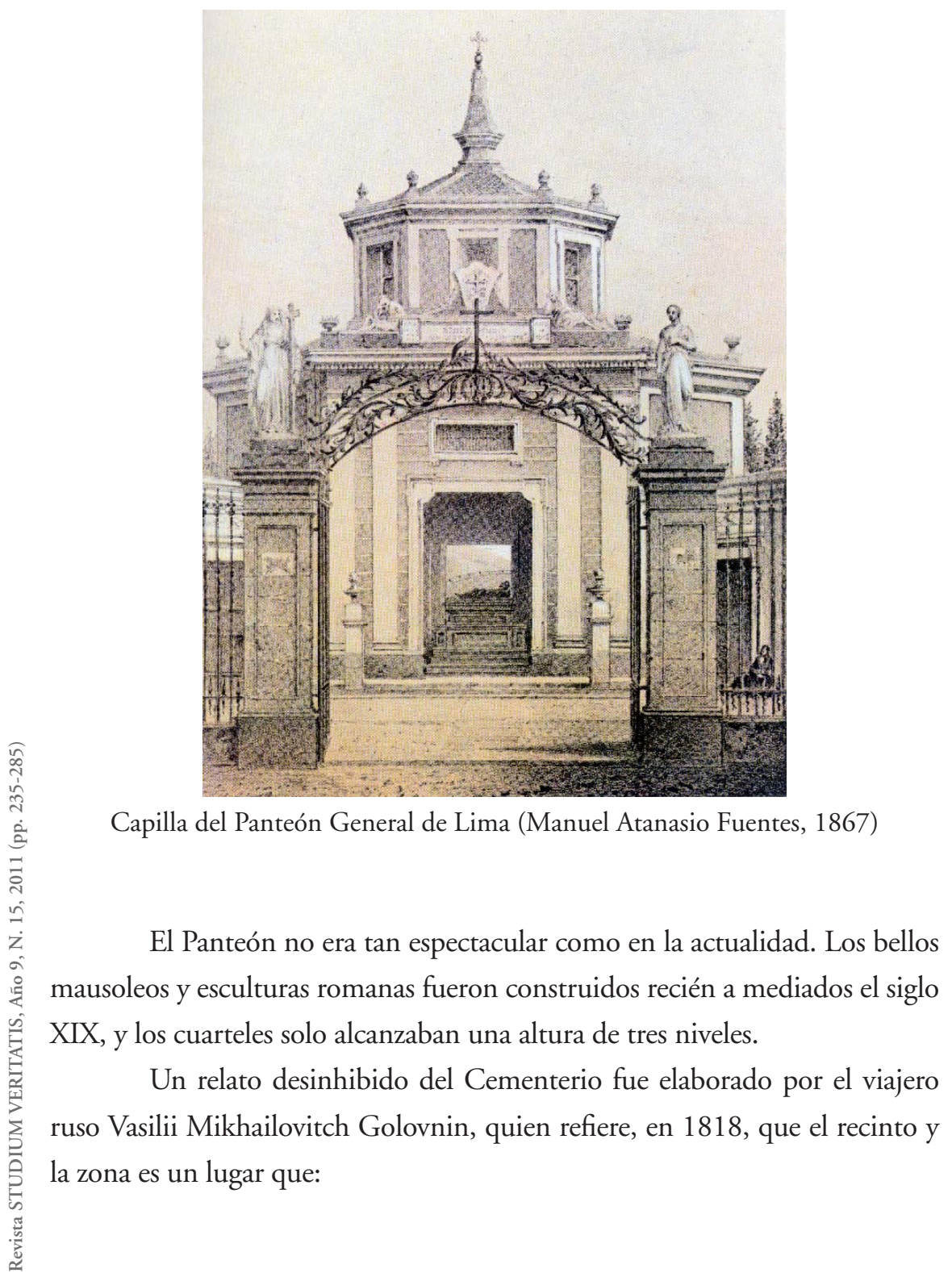


...no valen nada desde cualquier punto de vista, pero los españoles lo encuentran una maravilla y lo enseñan a los extranjeros como algo raro y fuera de lo común. El Panteón consiste en un edificio redondo, de altura y tamaño muy medianos, con dos alas pequeñas. Encima del centro del edificio se halla una pequeña cúspide, debajo de la cual hay un catafalco de lo más ordinario, sobre el que está colocado un ataúd de vidrio que contiene una representación de cristo hecha de cera con muy poco arte. En el techo de la cúpula está, pintados medianamente bien unos ángeles, querubines y serafines, en actitud de volar por varias partes. Al lado de esta capilla hay una extensión bastante amplia, cercada por un muro alto. Este sitio es el cementerio común de la ciudad. Sin embargo, no tiene ningún monumento ni piedras sepulcrales, como se ve en otros países. Para el entierro de gente acaudalada, que puede pagar 200 pesos por el sitio, han construido unos muros de ladrillos que tienen cerca de 10 metros de largo, 2 metros del alto y lo mismo de fondo. Estos muros tienen tres hileras de nichos que parecen desde afuera unas bocas de horno; se extienden casi todo lo ancho del muro y tienen un tamaño suficiente para que pueda entrar un ataúd. Después de colocar un ataúd en un nicho semejante, se tapa la entrada con ladrillos y barro. A veces ponen una lápida con inscripciones y epitafios, pero lo más común es poner un número, por lo que siempre se puede encontrar en los libros quién es el enterrado. Cuando se llenan todos los sitios en todos los muros sacan a los enterrados antiguos y ponen sus huesos en la tumba común mientras el nicho queda libre para nuevos muertos. En cuanto a los pobres, los meten sencillamente en la tierra. (Pacheco 1967: 367) 
Con la culminación del Cementerio se instauró también un Reglamento Provisional para el entierro de los cadáveres. El texto elaborado por Matías Maestro fue revisado por el Virrey José Fernando de Abascal y el Arzobispo de Lima, Bartolomé María de las Heras. ${ }^{7}$

Según este Reglamento uno de los personajes administrativos más importante era el colector, quien debía encargarse en un plazo no mayor de 15 días, de que todas las iglesias cierren de manera permanente sus bóvedas, sepulturas y osarios, salvo para el entierro de personas «venerables» y de santidad comprobada. Desobedecer esta orden implicaba el pago de una multa de 50 pesos, dinero con el que debía prevenir las infecciones generalizadas producto de la exhumación de cadáveres.

Este personaje, entre otras cosas, también estaba facultado para vender los nichos a un valor de 12 pesos, mediante la entrega de boletos o papeletas a terceras personas y representantes de cofradías o hermandades. El comprador adicionalmente debía abonar 2 pesos más para conducir el cadáver y 10 pesos para colocar el nicho.

El colector también era el encargado de prohibir en forma determinante el uso de escudos y epitafios recargados, así como adornar la sepultura con trofeos y otra clase de aditamentos. A su vez, los propietarios de los nichos especiales podían construir osarios particulares en los límites del área adquirida en donde podían colocar una puerta de bronce, la misma que no podía ser abierta hasta cuando se debía evacuar el entierro anterior.

7 Reglamento Provisional acordado por el Excelentísimo Señor Don José Fernando de Abascal y Sousa, Virrey y Capitán General del Perú, con el Ilustrísimo Señor Doctor Don Bartolomé María de las Heras, dignisimo Arzobispo de esta Santa Iglesia, para la apertura del Cementerio General de esta ciudad, conforme a lo ordenado por Su Majestad, en Reales Cédulas de 9 de diciembre de 1786, y 3 de abril de 787. AML. N. 43 Cementerio General, año 1808-1822, fol. 1-22. 
El Clero y las demás órdenes religiosas tenían reservado en forma gratuita la propiedad de sus nichos y por ningún motivo podía incrementarse la cantidad reservada para cada una de ellas.

Los párvulos por su parte debían ser enterrados en los nichos del Angelorio pagando tan solo 5 pesos y 2 pesos adicionales por la conducción. Pero en caso que los familiares desearan enterrarlo en un nicho de adulto, debían pagar los derechos como si fuera adulto.

En la exhumación de los cadáveres no se permitía a los familiares reutilizar los ataúdes ni traspasarlo a tercera persona. Ese derecho estaba reservado solo para los administradores del cementerio, quienes generalmente lo destinaban a personas de bajos recursos económicos.

El colector debía exigir a los párrocos y curas que inscriban los datos completos del occiso y ha donde debía ir a recogerlo el presbítero conductor. Los datos elementales eran: nombre, lugar y día de fallecimiento, sexo, casta, edad, procedencia, etc., los mismos que debían ser avalados con la rúbrica del cura.

Los carros fúnebres estaban a cargo del colector quien debía recoger el cadáver de las parroquias a las seis de la tarde, teniendo consigo las papeletas parroquiales y los documentos de la propiedad del nicho. Los carruajes por ningún motivo podían estar sucios y sin los aditamentos correspondientes para transportar los cuerpos. ${ }^{8}$

La norma establecía que el cadáver debía trasladarse en público o secreto desde la casa mortuoria a la parroquia o iglesia, en donde debía oficiarse una misa de cuerpo presente. Quedaba prohibido en forma terminante trasladarlo directamente al cementerio. Para realizar este traslado en forma reservada y

8 El carruaje jalado por tracción animal estaba compuesto por una caja especial en donde se depositaba el cuerpo del occiso y en donde la llave solo era manejada por el Presbítero Conductor, más no por el cochero. El carruaje se distinguía por la marca de una cruz $(\dagger)$. 
secreta, los familiares debían abonar 2 pesos adicionales, no sin antes inscribirlo en los libros parroquiales para constatar su fallecimiento.

Las iglesias por su parte estaban obligadas a mantener libres sus ambientes desde las 6 a las 8 de la mañana con la finalidad de brindar las comodidades respectivas a los deudos para las exequias fúnebres. De existir varias celebraciones mortuorias durante un mismo día, las iglesias podían ejecutar la misma disposición en sus capillas.

Para el traslado del cuerpo al cementerio, el presbítero conductor debía organizarse parta atender a todos el mismo día. Así, antes de iniciar sus labores trazaba su ruta.

Los únicos que podían ser trasladados en forma directa al cementerio eran aquellas personas que fallecían en los hospitales. En este caso, su traslado se realizaba luego de oficiar una oración y siempre y cuando la carroza estuviese libre. De no ser así, era recogido a las 6 de la mañana del día siguiente, llevando consigo una caja para evitar el hedor del cadáver. No pudiendo hacerlo en los términos descritos, el cuerpo debía ser trasladado al tercer día al cementerio con el ataúd clavado para así evitar la proliferación de olores putrefactos.

Cuadro 2. Personal que labora en el Panteón de Lima $(1820)^{9}$

\begin{tabular}{|l|c|l|}
\hline Personal & Cantidad & Remuneración \\
\hline Colector & 1 & 800 pesos anuales \\
\hline Capellán conductor & 1 & 720 pesos anuales \\
\hline Capellán conductor auxiliar & 2 & 500 pesos anuales \\
\hline Sacristán & 1 & 25 pesos mensuales \\
\hline Portero del Martinete & 1 & 15 pesos mensuales \\
\hline Esclavos & 9 & Manutención \\
\hline
\end{tabular}

9 No se menciona el instrumental ni los equipos que utilizaban los capellanes y demás empleados del Cementerio General. Reflexiones en apoyo de la incorporación del Cementerio General al Hospicio con benéfico de ambos establecimientos y del público. AML. N. 43 Cementerio General, año 1808-1822, fol. 15 y 16. 
El presbítero conductor era el encargado de recibir y trasladar los cuerpos de los fallecidos desde las iglesias al cementerio. Su itinerario a paso moderado dependía de cuantos cuerpos debía recoger durante el día.

Sus labores iniciaban a las 6 de la mañana recogiendo del colector los boletos con los datos de los occisos. Una primera parada era en el Martinete y de allí tomando el camino por fuera de la muralla, entraba al cementerio. El cochero debía prevenir que ningún carruaje le siga el camino. La carroza solo podía detenerse en caso de algún incidente como por ejemplo: cambiar de mulas, reparar las ruedas, etc.

El recojo de cuerpos por parte del presbítero conductor variaba de acuerdo a las estaciones. Así, en invierno podía iniciar sus labores a las cinco y media de la tarde, mientras que en verano media hora o una hora después, respectivamente. Este personaje estaba facultado para evacuar el cuerpo de las iglesias después de las ocho de la mañana, aun cuando el sacerdote no haya oficiado misa o sus familiares le hayan rendido los honores correspondientes.

El encargado de enterrar los cuerpos era el capellán. El segundo capellán, el sacristán y los sirvientes eran quienes ubicados en forma estratégica en las gradas del altar, sujetaban dos velas encendidas. Previo a ello debía inscribirlo en el libro de registro, así como posteriormente en el libro de la parroquia con la finalidad de dejar constancia de su fallecimiento.

Con este mismo propósito, el capellán debía conservar en forma ordenada los boletos y libros en el archivo. No podía proporcionar información de cualquier tipo. Esa labor estaba asignada a los párrocos.

El segundo capellán debía también rociar los cuerpos con agua bendita según el ritual romano. Adicionalmente debía conservar el aseo del cementerio y procurar el incremento de plantas y hierbas aromáticas que contrarresten algunos hedores propios de un lugar destinado para 
entierros. Con este mismo propósito quedaba prohibido el paso de recuas de mulas y el establecimiento de caballerías al interior del cementerio y en las inmediaciones.

El cuidado de los jardines fue una preocupación que tuvo en cuenta Matías Maestro al momento de edificar el cementerio, tal como lo evidencia un informe elaborado el 16 de abril de 1807: «[...] no puedo menos de poner en la alta consideración de V. E. la escasez de agua de aquel terreno para la conservación de los muchos árboles y yervas aromaticas, que deben formar su adorno con recreo y utilidad pública». ${ }^{10}$

Según sus observaciones la única solución posible era sacar una medida de agua de la acequia ubicada cerca del camino de Maravillas que utilizaban los capellanes y vecinos de la zona. La acequia en mención era alimentada por el río Surco y para extraer el riego de agua debía el Juzgado de Agua modificar los repartos establecidos a los hacendados que disfrutaban de ese recurso. Las negociaciones fueron tensas toda vez que el caudal del río Rímac era irregular y se necesitaba medio riego más para cubrir las necesidades del cementerio.

Ante esta situación y no queriendo entrar en mayores controversias con los hacendados de la zona, el Juzgado de Aguas dispuso abrir una nueva toma o «boquilla» en el valle de Cacahuasi, muy cerca de la toma perteneciente al Hospital Santa Ana. El agua también sirvió para establecer una pila para el uso de los capellanes quienes vivían en el lugar.

10 Informe de Matias Maestro acerca de la falta de agua en el Cementerio General. AML. N. 43 Cementerio General, año 1808-1822, fol. 1. 
Cuadro 3. Número de entierros del Panteón de Lima (1808-1817)

\begin{tabular}{|c|c|c|c|c|c|c|}
\hline Año & \multicolumn{4}{|c|}{ Muertos } & \multicolumn{2}{c|}{ Pobres } \\
\hline & Hombres & Mujeres & Párvulos & Total & Ad. & P.P. exp. \\
\hline 1808 & 925 & 611 & 897 & 2423 & 568 & 414 \\
\hline 1809 & 1504 & 977 & 1655 & 4136 & 1008 & 848 \\
\hline 1810 & 1299 & 879 & 1629 & 3807 & 1062 & 852 \\
\hline 1811 & 1367 & 903 & 1656 & 3916 & 1119 & 789 \\
\hline 1812 & 1588 & 1111 & 2040 & 4749 & 1566 & 1053 \\
\hline 1813 & 1363 & 939 & 1759 & 4061 & 1251 & 946 \\
\hline 1814 & 1109 & 830 & 1516 & 3455 & 1030 & 759 \\
\hline 1815 & 1147 & 859 & 1437 & 3443 & 1228 & 603 \\
\hline 1816 & 1149 & 878 & 1102 & 3499 & 1131 & 703 \\
\hline 1817 & 1187 & 873 & 1540 & 3600 & 1189 & 721 \\
\hline & 12598 & 8870 & 15631 & 37099 & 11152 & 7688 \\
\hline
\end{tabular}

Fuente: Resultado de la administración del Cementerio de Lima desde su apertura en 1 de junio de 1808 hasta 31 de diciembre de 1817. AML. N. 43 Cementerio General, año 1808-1822, fol. 1.

Luego de doce años de funcionamiento, en enero de 1820, Matías Maestro propone incorporar el cementerio al dominio de la Junta de la Real Beneficencia, aduciendo elevados gastos de conservación e inadecuada administración, además de tener que afrontar cerca de 68500 pesos de deuda a favor de los fondos de Obras Pías a razón de 3.5\% de interés anual, cantidad con la que se había sufragado los gastos de construcción. 


\section{Cuadro 4. Entradas y gastos del Panteón de Lima (1808-1817)}

\begin{tabular}{|c|c|c|c|c|c|c|c|c|}
\hline Año & \multicolumn{4}{|c|}{ Productos (Pesos y reales) } & \multicolumn{4}{|c|}{ Gastos (Pesos y reales) } \\
\hline & Conduc. & Nichos & Sellos & Total & Sueldos & Gastos & Retiros & Total \\
\hline 1808 & 3156 & 1540 & & 4,696 & $4,462.2$ & \multirow{2}{*}{$5,189.6$} & \multirow{2}{*}{$2,593.21 / 2$} & $12,245.2$ \\
\hline 1809 & 5333 & 2477 & & 7,810 & 2,820 & & & $1 / 2$ \\
\hline 1810 & 4678 & 2325 & & 7,003 & 2,795 & $2,229.5$ & $2,475.41 / 2$ & $7,525.11 / 2$ \\
\hline 1811 & 5012 & 3270 & & 8,282 & 2,795 & $2,255.7$ & $2,475.41 / 2$ & $7,526.31 / 2$ \\
\hline 1812 & 5382 & 3435 & & 8,817 & 2,865 & $2,362.21 / 2$ & $2,475.41 / 2$ & $7,632.7$ \\
\hline 1813 & 4680 & 2950 & & 7,630 & 2,940 & $2,422.61 / 2$ & $2,475.41 / 2$ & $7,763.3$ \\
\hline 1814 & 4046 & 2385 & & 6,381 & 2,940 & $2,142.4$ & $2,475.41 / 2$ & $7,5581 / 2$ \\
\hline 1815 & 4134 & 3229 & & 7,363 & 2,940 & $2,267.2$ & $2,475.41 / 2$ & $7,682.61 / 2$ \\
\hline 1816 & 4604 & 2725 & & 7,329 & 2,940 & $2,270.71 / 2$ & $2,475.41 / 2$ & $7,686.4$ \\
\hline \multirow[t]{2}{*}{1817} & 4390 & 2351 & 243.4 & $6,984.4$ & 2,940 & $2,004.5$ & $2,475.41 / 2$ & $7,420.11 / 2$ \\
\hline & 45415 & 26637 & 243.4 & $72,295.4$ & $27,497.2$ & $23,145.5^{1 / 2}$ & $22,397.6 \frac{1}{1} 2$ & $73,040.6$ \\
\hline
\end{tabular}

Fuente: Resultado de la administración del Cementerio de Lima desde su apertura en 1 de junio de 1808 hasta 31 de diciembre de 1817. AML. N. 43 Cementerio General, año 1808-1822, fol. 1

Según este cuadro en los nueve años y siete meses de funcionamiento, el cementerio gastó más de 73000 pesos, de los cuales más de 27000 pesos fueron destinados a sueldos y más de 23000 a gastos diversos. 
Cuadro 5. Resultado de la administración del Panteón de Lima (1808-1817)

\begin{tabular}{|c|c|c|}
\hline Año & \multicolumn{2}{|c|}{ Resultado anual (Pesos y reales) } \\
\hline & Sobrante & Faltas \\
\hline 1808 & 260.5 & \\
1809 & & $522.2^{1 / 2}$ \\
\hline 1810 & & \\
\hline 1811 & $755.4^{1 / 2}$ & 133.3 \\
\hline 1812 & $1,184.1$ & $1,177^{1 / 2}$ \\
\hline 1813 & & $319.61 / 2$ \\
\hline 1814 & & 357.4 \\
\hline 1815 & & $435.51 / 2$ \\
\hline 1816 & & $2,945.5$ \\
\hline 1817 & & \\
\hline & $2,200.22 / 4$ & \\
\hline
\end{tabular}

Fuente: Resultado de la administración del Cementerio de Lima desde su apertura en 1 de junio de 1808 hasta 31 de diciembre de 1817. AML. N. 43 Cementerio General, año 1808-1822, fol. 1

Esta cantidad comparada a los 72295 pesos 4 reales de ingresos, arroja un déficit de 745 pesos y 2 reales, que aunados a los 7198 pesos de deuda de construcción, se tiene como resultado 7943 pesos 5 reales. Esta es sin duda la mejor razón para desligarse de la administración del cementerio, la cual se hace efectiva a partir de julio de 1820 .

Establecida la independencia peruana y luego de más de quince años de administración republicana, el Cementerio o Panteón General cambió de nombre de manera oficial en 1837. Desde ese año asumió la denominación de Presbítero Matías Maestro en homenaje al sensible fallecimiento de tan reconocido y polifacético personaje ocurrido en enero de 1835.

Durante esta época y hasta los albores de la guerra con Chile, se construyó más cuarteles para satisfacer la creciente demanda de la población 
de Lima y alrededores. Hasta la cuarta década del siglo XIX, los cuarteles contaban con tan solo tres hileras de nichos, aumentando a cuatro a mediados de siglo y proyectándose a cinco hileras durante las siguientes décadas. Es necesario advertir el incremento de tumbas individuales y colectivas, así como la construcción de mausoleos.

En un breve recorrido por el actual cementerio no se logra ubicar lápidas cuya antigüedad se remonten más allá de 1830, en vista de las innumerables remodelaciones a la que fue objeto, así como a las selectivas sustracciones.

La suntuosidad que hoy ostenta el cementerio fue adquirida a mediados del siglo XIX, la misma que responde no solo a la moda y estilos artísticos del momento, sino también a la boyante economía exportadora de materias primas. En este sentido, el incremento favorable de la balanza de pagos del comercio exterior dio la posibilidad de concretar ideales funerarios y mausoleos imaginados solo entre sueños.

A pesar de la inestabilidad política ocurrida durante las primeras décadas de vida republicana, la economía peruana creció gracias a la exportación de guano y salitre, sin dejar de mencionar el cobre, cacao, lana de alpaca, algodón y sobre todo el azúcar. Este último producto incrementó su exportación incluso hasta los albores de la guerra con Chile, tal como lo evidencia el aumento de las 69828 toneladas de azúcar entre 1869 y 1878. De este volumen, doce toneladas eran destinadas para el consumo interno y más de 69005 toneladas para el mercado europeo.

El desastre y bancarrota de la economía peruana luego de la guerra con Chile, así como las campañas militares en Lima, han sido investigadas por diversos especialistas nacionales y extranjeros (Basadre, 1969; Benavides, 1972; Quiroz Norris, 1969; Bonilla, 1982; Palacios, 1987; etc.). Sin embargo, en ninguno de sus escritos se puede encontrar noticias acerca de ¡cuál fue 
la actitud que asumieron los soldados chilenos con las instalaciones de los cementerios al momento de ocupar Lima? Responder a esta interrogante es importante toda vez que el ejército sureño desmanteló y saqueó las principales haciendas, iglesias e instituciones de administración gubernamental.

$\mathrm{La}$ inexistente información sobre el tema nos induce a pensar que el cementerio fue respetado debido a que la mayoría de los soldados profesaba la religión católica, la misma que condenaba la profanación de tumbas y nichos. Adicionalmente, debe tomarse en cuenta cierto grado de superstición y respeto hacia los muertos y la muerte, que de seguro en más de una ocasión debió haberse cruzado con él en los campos de batalla. Por último no debemos olvidar que un gran número de chilenos habían sido sepultados en los diferentes cementerios de Lima.

El único relato acerca del Presbítero Maestro durante esta época corresponde a Middendorf, quien durante 25 años recorrió casi todo el país, llegando incluso a presenciar la guerra con Chile. Él describe al cementerio como uno de los lugares más bellos de Lima:

El Cementerio se halla en la parte alta, fuera de la ciudad; se extiende hasta cerca del río, y está a muy poca distancia de los cerros de San Bartolomé, que cierran el valle por el este. Toda la obra y sus nichos y monumentos, hacen que el cementerio sea una de las cosas más dignas de verse en Lima. El camino pasa por delante del Hospital de incurables y del Lazareto, a través de la antigua portada de Maravillas, que está a una distancia de medio kilómetro del cementerio. Delante de la entrada, se ensancha la calle formando una plaza semicircular, en cuyo centro, se levanta sobre una pequeña columna la estatua del Ángel de la Muerte, que señala hacia la puerta. Toda la parte anterior al cementerio, al que ingresamos ahora, está separada de la calle por una reja de 
hierro, a través de cuyos barrotes se divisa un jardín muy bien cuidado, que rodea la capilla próxima a la puerta principal. Entre arbustos, flores o bajo sombra de altos árboles se levantan los mausoleos, grandes y pequeños, capillas, estatuas y bustos, casi todos ellos de mármol y muchos, de valor artístico.

Aquí encontraron finalmente su último descanso todos los desasosegados espíritus que empujados en vida por su desenfrenada ambición precipitaron a su patria en terminables guerras civiles, y los que fueron enemigos encarnizados, yacen ahora en pacífica vecindad. (Middendorf 1973 [1893]: 363)

Pasada la guerra con Chile y tomando en cuenta los apuros económicos del gobierno peruano, el cementerio no recibió ningún apoyo económico del Estado para efectuar algún tipo de mantenimiento, pues la prioridad estaba centrada en la recuperación del crédito público y la reactivación de las principales actividades económicas. Es así como las familias de los difuntos fueron los únicos en sufragar los gastos de funcionamiento con el pago de los derechos de sepultura, compra de nichos y terrenos para construir tumbas y mausoleos individuales o múltiples.

Durante esta época la administración del cementerio no estaba a cargo de la municipalidad ni del Estado sino de la Beneficencia Pública de Lima, cuyos principales ingresos provenían de la venta de nichos y tumbas de manera perpetua o temporal. Esta última modalidad podía ser de tres o cinco años renovables. 


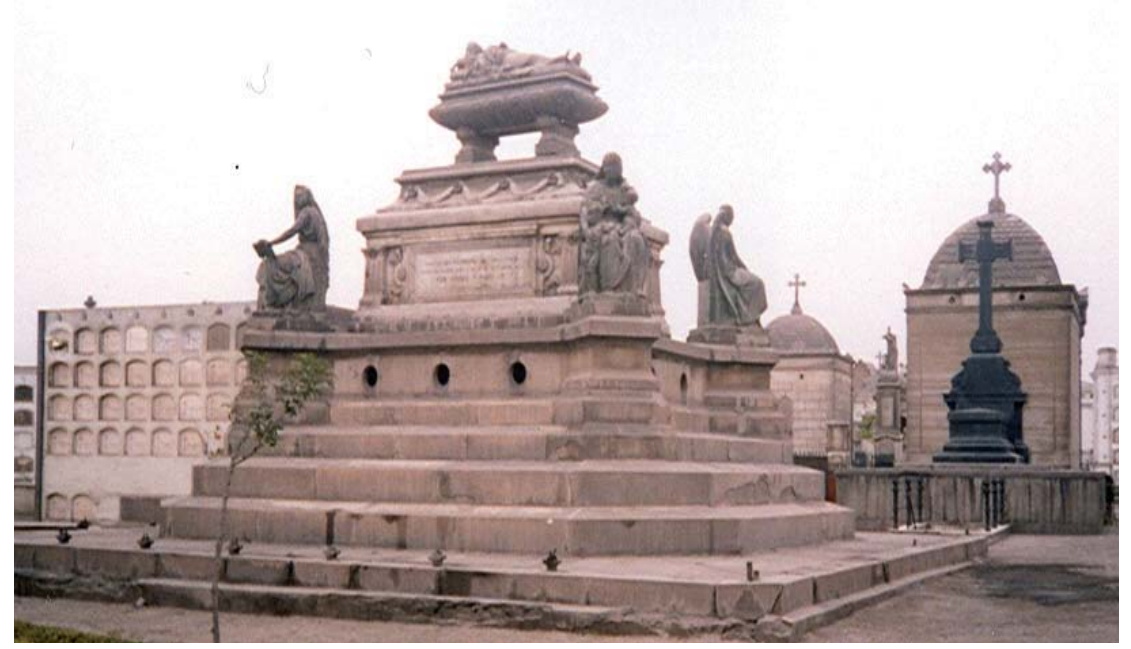

Mausoleo de Sofía Bergamann de Dreyfus - 1871 (Archivo Santiago Tácunan, 2005)

En sus inicios el costo de los nichos perpetuos eran de 12 pesos, los mismos que subieron a 200 pesos a mediados del siglo XIX y luego de la guerra con Chile se redujo a 50 pesos. En lo que respecta a los nichos temporales, los familiares en la última década del siglo XIX debían abonar cuatro pesos por el uso de un nicho durante tres años. Vencido el plazo, los deudos podían renovar el contrato.

Con el paso de los años y el incremento oscilante de la demanda del mercado europeo, la economía peruana recuperó su prestancia. Este desarrollo permitió a su vez que la gente modifique de manera sustancial sus costumbres funerarias. 
Cuadro 6. Comercio Exterior del Perú (1913-1920) (millones de soles)

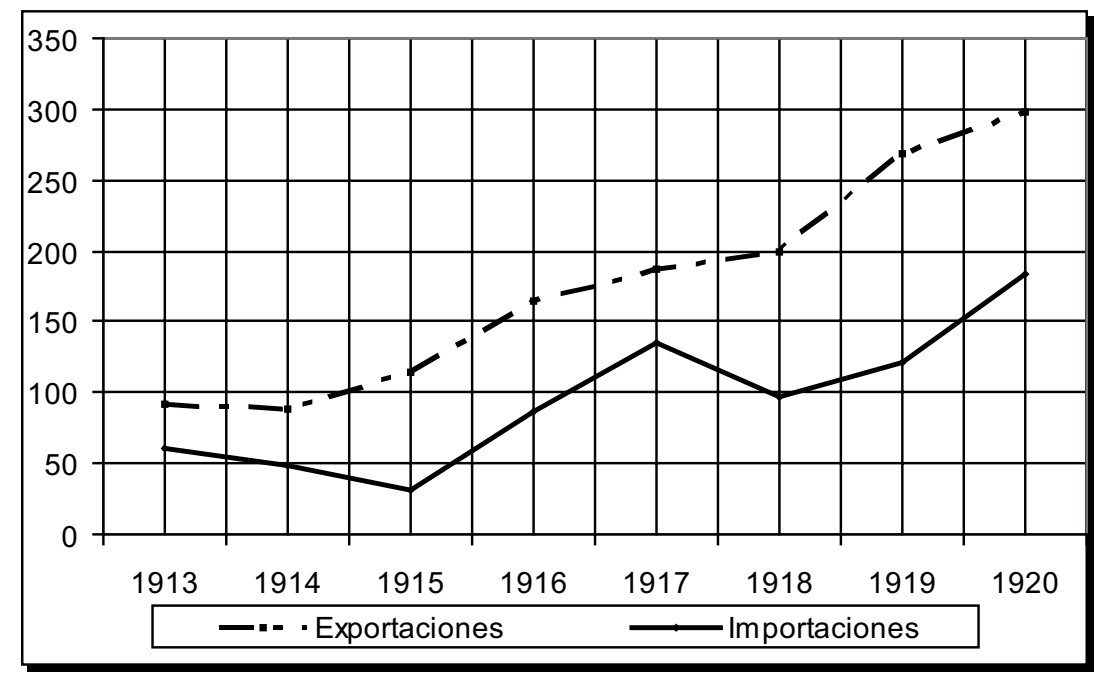

Fuente: Bardella 1989: 203

La aristocrática sociedad limeña prefería la iglesia de La Merced, Santo Domingo, San Francisco, San Agustín y San Pedro para desarrollar las exequias fúnebres. Aunque no era una regla formal, la Catedral de Lima estaba reservada para desarrollar los funerales de las principales autoridades y personajes ilustres.

Por su parte, la clase menos pudiente utilizaba las iglesias de Santa Ana, Los Huérfanos, Trinitarias, Los Descalzos, Del Patrocinio, Santa Liberata, Copacabana, Santa Cristo, Santa Clara, San Sebastián, Santiago del Cercado, San Lorenzo, Soledad, Buena Muerte, entre otras.

Durante la república y considerando las oscilaciones del comercio exterior, las familias de clase alta no solo prodigaron esfuerzos por plasmar inscripciones y mensajes en las lápidas, sino también por construir amplios 
y complicados mausoleos artísticos. No olvidaban de publicar en los principales periódicos de Lima la lamentable defunción, así como contratar pregones para esparcir la noticia en las principales y más concurridas calles y plazas de Lima.

Un entierro era calificado como bueno cuando se desarrollaba los siguientes aspectos:

- Pompa exhibida durante el cortejo fúnebre

- Lugar escogido para el entierro

- Temporalidad del espacio mortuorio

- Calidad del material de construcción

- Trabajo artístico

- Número de asistentes a la misa

- Realización de misas simultáneas

- Comida y bebida servida a los asistentes.

Luego de la ceremonia religiosa el cuerpo era trasladado al cementerio en medio de un gran dolor exteriorizado por las famosas «lloronas». Una vez en el lugar, el cadáver era depositado en el nicho e inmediatamente se esparcía cal hidráulica. Luego de tapiar la entrada se colocaba una lápida de mármol o una inscripción protegida por vidrio. En el caso de los entierros temporales y no habiendo sus familiares renovado el contrato, el cadáver podía ser retirado del nicho y depositado en bóvedas.

Los cuerpos de la gente de escasos recursos económicos eran enterrados con o sin cajón en un área adyacente al cementerio (fosa común de 12 a 15 pies de profundidad) sin mayores celebraciones. Este tipo de 
entierro solo se efectuaba durante la mañana. Una vez ubicado el cuerpo era inmediatamente cubierto con una gruesa capa de cal y tierra. Este procedimiento continuaba hasta cubrir la capacidad de la fosa.

\section{Cuadro 7. Entierros en el Presbítero Maestro (1879-1883) ${ }^{11}$}

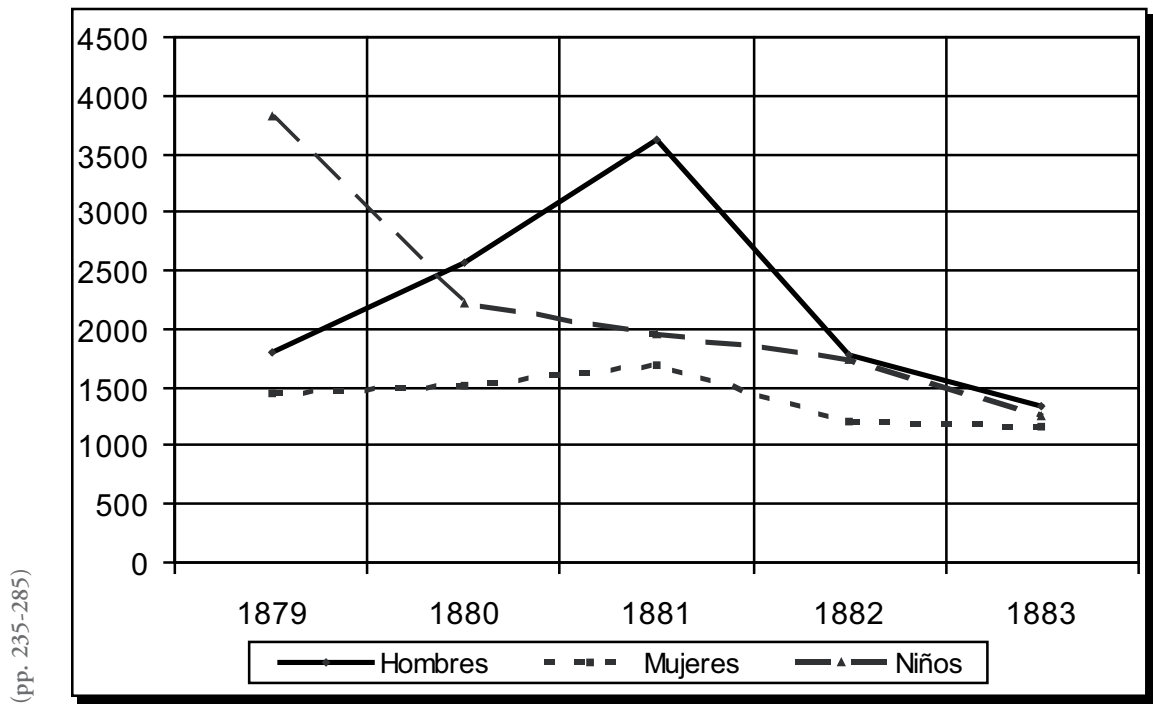

Si bien un estudio acerca de los estilos góticos y medievales de los mausoleos y criptas del Presbítero Maestro, así como una investigación especializada de la iconografía y alegoría existente en diversas placas de mármol, es todavía una tarea pendiente, es necesario mencionar lo siguiente: las imágenes y símbolos se diferencian social e ideológicamente

11 El número de entierros de hombres se incrementó durante 1880 y 1881, como consecuencia de la guerra con Chile, pues muchos de ellos fueron heridos de manera mortal (Cf. Middendorf 1973 [1893]: 395). 
en un primer momento, para luego ser usados de manera indistinta por diversos grupos sociales tratando de expresar mejor sus sentimientos. Por lo general la iconografía es de sentido religioso, aunque también existen manifestaciones de corte liberal relacionada con las ciencias naturales y representaciones que expresan virtudes de la vida humana del difunto de manera particular.

En términos generales el siglo XIX es un periodo de secularización que se manifiesta más profundamente en el tema de la muerte, aunque claro está con algunos intentos por mantener la tradición establecida. Este proceso se puede apreciar en los testamentos que no hace mayores referencias religiosas como durante la época colonial. Las principales y únicas reverencias están relacionadas a mencionar que son cristianas y católicas. ${ }^{12}$ Este cambio o laicización de los testamentos obedece a una nueva concepción de la muerte, en donde la familia es la responsable de la ceremonia fúnebre.

Saber cuando una persona había sido enterrada en la iglesia o convento, a pesar de la prohibición existente, era relativamente fácil. La mejor prueba era el inicio de alguna pandemia, originada por el hedor de los cadáveres al momento de abrir las bóvedas subterráneas.

Una costumbre colonial que se mantuvo durante la república fue la de retornar a la casa del difunto y permanecer en él largas horas, hasta despedirse, acto con el que se concluía la ceremonia. Una hora prudente para retirarse eran las ocho de la noche.

Algo que también perduró a pesar de los años fue considerar el entierro de los niños como un acto de gloria y júbilo, en vista que los padres creían fervientemente que enviaban al cielo a un ángel sin el temor de

12 AGN. Escribano Manuel Orellana, Protocolo N. 548, año 1889, fol. 332. 
que tuviera que pasar por el trance doloroso del purgatorio. El cuerpo del infante era amortajado como un ángel, debido a la sólida creencia de que pasaba a formar parte del ejército de ángeles que rodean a Dios.

No es nuestra intención analizar las lápidas y hacer un estudio detallado y artístico de los mausoleos familiares e individuales existentes en los principales cementerios de Lima. Menos aún de las necrologías que Carlota Casalino ha analizado en su tesis de Maestría acerca de «La muerte en Lima en el siglo XIX». Sin embargo, es importante mencionar que esto último fue muy generalizado llegando a saturar las páginas sociales de los diarios limeños:

En ellas se hacía expresa referencia al comportamiento positivo del difunto, su vida se convertía en un paradigma, en un ejemplo. En ese sentido, se sancionaba una conducta pública que debía ser la que permanecería en el recuerdo de los limeños. De esa manera se producía el proceso denominado por los antropólogos como muerte social; es decir, el lugar que los difuntos comienzan a ocupar en la comunidad luego de su fallecimiento. ${ }^{13}$

A pesar de los cambios en la mentalidad de la población acerca de la muerte, casi nadie dejó de usar la mortaja, aunque sin mantener la idea original de penitencia y ayuda al difunto con la finalidad de cruzar con éxito el camino del purgatorio. En este sentido, el uso de esa prenda sirvió solo como un aditamento de exterioridad y costumbre superflua.

13 Citando a José Gálvez, Casalino (2003: 37-46) informa que la primera necrología fue publicada por El Comercio el 5 de agosto de 1839, anunciando el fallecimiento de Fray Ramón Rojas, de la orden Franciscana. 


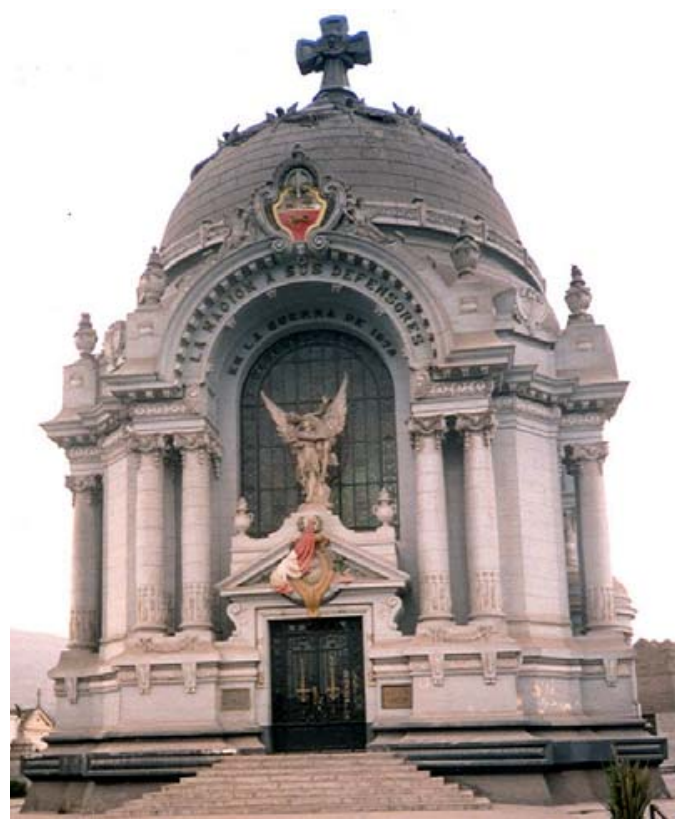

Cripta de los Héroes - 1908 (Archivo Santiago Tácunan, 2005)

Luego de varias décadas de vida republicana y teniendo en cuenta el incremento demográfico de la población de Lima y El Callao, se inició la construcción de varios cementerios, algunos más cerca al litoral. Es así como surge el Cementerio Británico, el Baquíjano, el Israelita y El Ángel. ${ }^{14}$

\section{EL CEMENTERIO BRITÁNICO DE BELLAVISTA}

Por lo general la historiografía peruana consigna la presencia británica en el Perú a partir de 1890, cuando el gobierno peruano firmó el Contrato Grace

14 En la actualidad existen también los cementerios Campo Fe y Jardines del Buen Retiro en varios distritos de Lima. 
con los Tenedores de Bonos de la Deuda Externa a quienes les concedió el uso de las principales vías ferroviarias del Perú (Paita-Piura, Pacasmayo, Trujillo, Chimbote, Central del Perú, Pisco y Sur del Perú). ${ }^{15}$

Sin embargo, su presencia puede ser rastreada desde inicios de la república en donde eran vistos como fuente potencial para introducir innovaciones tecnológicas y capitales financieros al país. Para lograr estos propósitos, el gobierno peruano dictó algunas leyes y normas para alentar la naturalización y residencia de los extranjeros. Aunque debido a lo contradictorio entre algunas de ellas, poco se logró. En este sentido, el matrimonio resultó la mejor herramienta para obtener la nacionalidad peruana.

\section{I. Británico Antiguo ${ }^{16}$}

Luego de algunos años de permanencia, la Colonia Británica logró que el gobierno les otorgue a perpetuidad un amplio terreno en el Callao para construir un cementerio.

Si bien fue bautizado con el nombre de Cementerio Británico de Bellavista, en 1834, el lugar también sirvió para enterrar a difuntos de diferentes nacionalidades. Aunque el decreto de creación provincial menciona el 20 de agosto de 1836, el lugar comenzó a funcionar dos años antes gracias al apoyo de Andrés de Santa Cruz. ${ }^{17}$

15 El Contrato también contempló la administración de los Vapores del Titicaca, dos millones de toneladas de guano, dos millones de hectáreas de tierras en el Perené, pago de anualidades, etc. Algunas de estas cláusulas fueron modificadas en 1907 y 1928 . Véase University College Of London. Memorandum. The Peruvian Corporation Ltd., 1896, pp. 20-40; y The first fifty years of the Peruvian Corporation Ltd. 1890-1930, pp. 18-35.

16 Este cementerio es poco conocido y por lo general es confundido con el cementerio Británico Moderno, ubicado en la Av. Colonial. Este camposanto se haya a la espalda de la Comisaría de Guardia Chalaca (cruce de las avenidas Guardia Chalaca y Colonial).

17 El título de Provincia Constitucional fue conferido por la Convención Nacional mediante Decreto del 22 de abril de 1857 (Lozada 2000: 615 y 616). 
El lugar fue ideal para enterrar a los ingenieros de la Peruvian Corporation que fallecían a causa de las fiebres producidas por la picadura de los mosquitos (Phlebolomus), cuyo veneno desencadenaba la enfermedad de la verruga que en un $85 \%$ de los casos era mortal. Para recordar este lamentable episodio la empresa o los familiares de los ingenieros colocaban en las lápidas consignas acerca de las causas de su muerte, como por ejemplo: «murió de verruga» $\mathrm{O}$ «muerto por la verruga». ${ }^{18}$

Para reducir los índices de mortandad de los obreros y del personal técnico, la Peruvian, teniendo en cuenta los estudios de investigación de Daniel Alcides Carrión, ordenó adelantar la jornada laboral y que ningún trabajador duerma en los alrededores de las obras ferroviarias en donde se habían instalado los campamentos. En este sentido, al término de la jornada casi todos debían ser trasladados a Chosica o a pueblos ubicados a menor altura. Los únicos que podían permanecer en el lugar cuidando los materiales de construcción, eran personas que pertenecían a la zona y que aparentemente parecían inmunes a la picadura de los Phlebolomus.

Esta estrategia fue puesta en práctica porque solo de noche atacaba ferozmente el mosquito, mientras que durante el día duerme en los arbustos y hendiduras de las rocas del río, siendo muy remoto el peligro de picaduras.

El cementerio está ubicado en la avenida Prolongación Zarumilla s/n., a la espalda de la Comisaría de Guardia Chalaca en Bellavista. El lugar cuenta con personal de seguridad y cerco perimétrico. A diferencia de la sede moderna, este no cuenta con espacio para albergar más difuntos.

18 Los obreros que padecieron esta enfermedad eran enterrados en los cementerios aledaños a la obra ferroviaria y en el mejor de casos trasladados a sus pueblos de origen. 


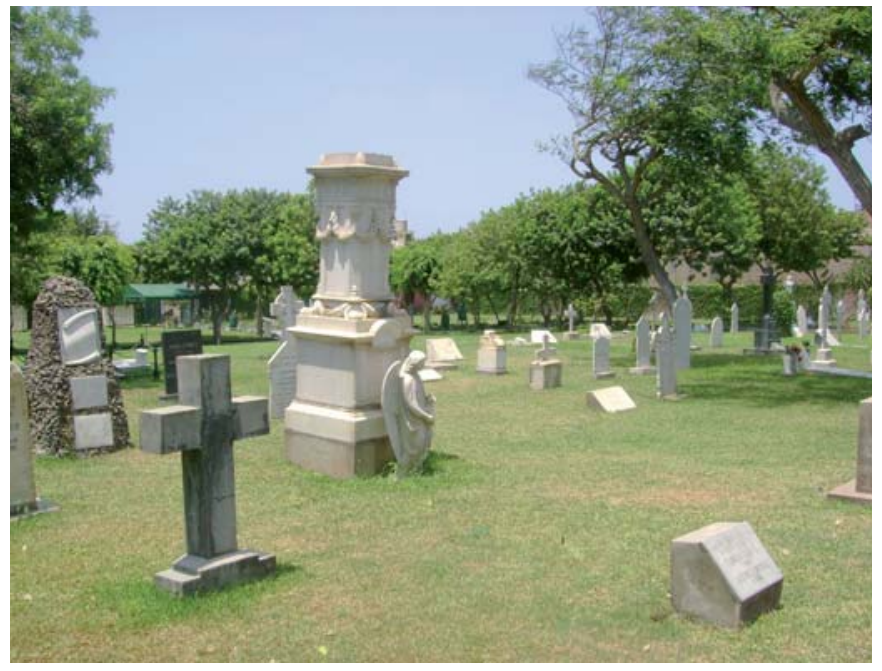

Vista general del cementerio (Archivo Santiago Tácunan, 2005)

\subsection{Británico Moderno}

La sede moderna está ubicada en la avenida Mariscal Oscar R. Benavides (ex avenida Colonial) N. 2141, en la Provincia Constitucional del Callao. Sus orígenes se remontan alrededor de la década del '70 del siglo XX, y a diferencia de la sede antigua, todavía cuenta con espacio libre para acoger difuntos. Los espacios disponibles tienen un costo elevado.

Los servicios que brinda al público, además del crematorio, son los siguientes:

- Cinerarios en tierra: seis urnas de cenizas en cada fosa.

- Columbarios: nichos cenizas para dos y cuatro urnas.

- Sepultura en tierra: tres entierros más cuatro urnas de cenizas en la cabecera de la fosa lo que hacen siete entierros en cada fosa. 
Los velatorios se realizan las 24 horas durante todo el año. El velatorio y la capilla pueden ser utilizadas por el público en general, previo pago por el uso de las instalaciones.

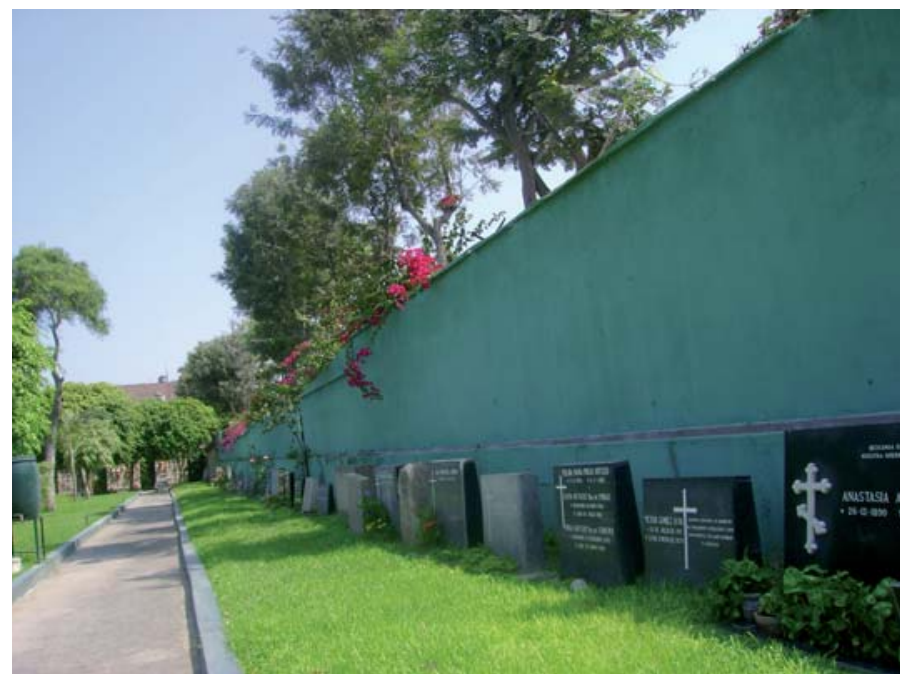

Avenida lateral del cementerio (Archivo Santiago Tácunan, 2005)

\section{EL CEMENTERIO BAQUÍJANO Y CARRILLO}

En 1857 y luego de haber soportado una serie de epidemias y pestes que asolaron Lima y Callao, Gregorio Hurtado, Director de la Sociedad de Beneficencia Pública del Callao, propone crear un nuevo cementerio. ${ }^{19}$

19 La Sociedad de Beneficencia Pública del Callao se estableció el 1 de diciembre de 1848 por Decreto Supremo del 28 de octubre que disponía el establecimiento de Sociedades de Beneficencia en todo el Perú. Su primer presidente fue el General Alejandro Deustua, quien junto a Manuel Cipriano Dulanto (Director), José Dañino (Vice Director), José María Urreiti (Tesorero), Juan Olivera (Inspector), Manuel Domínguez (Inspector), Juan Elisalde (Conciliador), Toribio Sanz (Conciliador) y Antonio de la Roza (Secretario), 
Hasta esos años y a pesar de las prohibiciones existentes, muchas personas del litoral enterraban a sus muertos en una pequeña huaca conocida como «Las Chacaritas», lugar que en la actualidad ocupa el Barrio de Chacaritas.

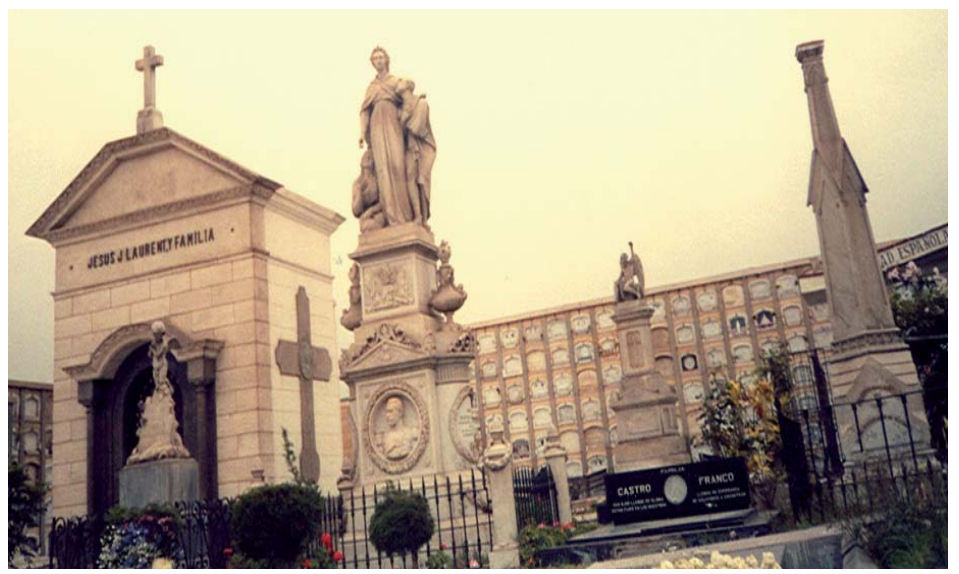

Vista general de la margen derecha de la avenida principal (Archivo Santiago Tácunan, 2005)

Si bien el lugar estaba algo alejado de la zona urbana, el terreno no era el más apropiado, pues los deudos enterraban a sus difuntos en medio de un gran lodazal y una nube de insectos, debido a la filtración de agua. Ante esta situación se eligió un lugar ubicado en el antiguo camino Lima-Callao (hoy avenida Colonial).

Adquirir el terreno no fue una tarea fácil, pues la Sociedad de Beneficencia tuvo que seguir un largo juicio de expropiación forzada en

formaron el primer Directorio. La Sociedad además del Cementerio Baquíjano, construyó y tuvo a su cargo el Hospital de Guadalupe (1836), El Lazareto del Callao (1853), Ferrocarril a la Punta (1863) y Hospital San Juan de Dios (1872). ASBPC. Socios de Beneficencia (1848-1878). 
contra de Ygnacia Ramírez de Arellano, dueña del terreno elegido para la construcción del cementerio.

Superado este inconveniente y habiéndose nombrado al arquitecto para levantar el plano de construcción y calculado el costo de la obra en 200 mil pesos, se buscó fuentes de financiamiento. Los primeros 20000 pesos fueron donados por Mariano Miguel Ugarte, 34562 pesos más provinieron de la venta de una parte del terreno denominado «Chacarita», 10000 pesos del gobierno que junto a los 55562 pesos destinados con anterioridad, suman un total de 120124 pesos.

La primera piedra fue colocada el 14 de octubre de 1859 y luego de varios años de arduo trabajo fue inaugurado el 31 de diciembre de 1861 bajo el nombre de Cementerio General de Baquíjano.

El bautizo de tan importante obra estuvo a cargo del Párroco José Tomás Mateus en representación del Vicario General del Arzobispado. A tan importante ceremonia asistió el presidente de la República Mariscal Ramón Castilla, quien en su discurso hizo alusión que la construcción respondía a una necesidad de higiene pública. ${ }^{20}$

Cuadro 8. Número de nichos temporales de adultos y párvulos

\begin{tabular}{|c|c|c|c|}
\hline Departamentos & Adultos & Departamentos & Párvulos \\
\hline San Narciso & 140 & Santa Marta & 348 \\
\hline San Claudio & 95 & San Luis & 510 \\
\hline San Martín & 95 & Total & 858 \\
\hline San Leocadia & 140 & & \\
\hline San Antonio & 140 & & \\
\hline Total & 610 & & \\
\hline
\end{tabular}

20 Fuente:<www.chimpum-callao.com/historia/cementerio.html>. 
Los primeros cadáveres enterrados fueron de Gertrudis Santana y Felipe de la Llaga, así como de la párvula Manuela Sofía de Quiros. Durante los primeros años de funcionamiento existieron siete y dos departamentos de nichos perpetuos de adultos y párvulos, respectivamente, así como cinco y dos departamentos de nichos temporales para ambos casos.

Cuadro 9. Número de nichos perpetuos de adultos y párvulos ${ }^{21}$

\begin{tabular}{|c|c|c|c|}
\hline Departamentos & Adultos & Departamentos & Párvulos \\
\hline San Fidel & 125 & Santa Rosa & 396 \\
\hline San José & 125 & Santa Genoveva & 492 \\
\hline San Gregorio & 125 & Total & $\mathbf{8 8 8}$ \\
\hline San Joaquín & 125 & & \\
\hline San Rosendo & 125 & & \\
\hline San Cipriano & 125 & & \\
\hline San Roque & 125 & & \\
\hline Total & $\mathbf{8 7 5}$ & & \\
\hline
\end{tabular}

Desde su funcionamiento hasta la actualidad el cementerio alberga a los difuntos de la provincia del Callao, Bellavista (1836), La Punta (1915), Carmen de La Legua (1964), La Perla (1964), Ventanilla (1969), así como otras zonas de Lima.

21 De los 125 nichos del departamento de San Vicente se destinó 10 para las Hermanas de la Caridad. 
Cuadro 10. Nichos temporales (1924-1938)

Índice por cuarteles

\begin{tabular}{|c|c|c|c|}
\hline Cuarteles & Primero & Segundo & \\
\hline San Fidel & 01 & 159 & Adultos \\
\hline San Carlos & 06 & 226 & Adultos \\
\hline Laico No 1 & 11 & 170 & Párvulos \\
\hline Laico No 2 & 43 & 289 & Adultos \\
\hline Laico No 4 & 41 & 192 & Párvulos \\
\hline Laico No 5 & 50 & & Adultos \\
\hline San Andrés & 16 & 182 & Adultos \\
\hline Santa Micaela & 20 & 187 & Adultos \\
\hline San Calixto & 26 & & Párvulos \\
\hline San Alberto & 35 & 134 & Párvulos \\
\hline San Rafael & 46 & 199 & Adultos \\
\hline San Miguel & 59 & 194 & Adultos \\
\hline San Pedro & 59 & Libro siguiente folio 29 & Adultos \\
\hline San Luis & 63 & 231 & Párvulos \\
\hline Santa Clara & 71 & 203 & Adultos \\
\hline Santo Toribio & 79 & & Adultos \\
\hline La Paz & 85 & & Párvulos \\
\hline Santa Eulalia & 94 & 211 & Adultos \\
\hline San Pablo & 101 & 218 & Adultos \\
\hline San Eustaquio & 109 & & Párvulos \\
\hline San Bernabé & 118 & Libro siguiente folio 33 & Adultos \\
\hline San Nicolás & 125 & 242 & Adultos \\
\hline Los Ángeles & 129 & 138 & Párvulos \\
\hline San Santiago & 141 & 247 & Adultos \\
\hline San Lázaro & 146 & Libro siguiente folio 4 & Adultos \\
\hline San Elías & 154 & Libro siguiente folio 39 & Adultos \\
\hline Santa Isabel & 164 & Libro siguiente folio 23 & Adultos \\
\hline El Silencio & 174 & & Párvulos \\
\hline
\end{tabular}

Fuente: ASBPC. Indice de cuarteles, nichos temporales (1924-1938).

El cementerio combina una parte antigua y moderna en donde sobresalen los nichos perpetuos italianos, al igual que los mausoleos franceses, la Gran Cruz ubicada al final de la entrada y las imágenes pintadas en las paredes de algunos cuarteles, distinguiéndose el de la creación de la humanidad. 
El área posee considerables jardines y un cerco perimétrico vigilado durante el día y la noche. La administración está a cargo de trabajadores adscritos a la Sociedad de Beneficencia Pública del Callao.

\section{EL CEMENTERIO ISRAELITA ${ }^{22}$ DEL CALLAO}

Aunque no se sabe con exactitud y de manera oficial cuando llegó el primer judío al Perú, se tienen indicios de su presencia a mediados de la década del '30 del siglo XIX, según los relatos de Flora Tristán citados por Günther Böhm (Cf. 1985:3).

A su llegada a Lima y con el ánimo de establecerse, los judíos desempeñaron una serie de labores profesionales circunscritas a funciones administrativas en diversas empresas privadas y públicas. No faltó quienes se dedicaron al comercio de productos europeos y a realizar algunas presentaciones artísticas como conciertos de piano y violín. Estos últimos solo estuvieron de paso por el Perú.

Hablar de una presencia judía más notoria es hablar de mediados del siglo XIX, época en que Europa entró en crisis y convulsiones sociales que obligó a muchas familias judías cultas emigrar a diversas partes de Europa y Sur y Norte de América.

Por razones de viaje y trayecto, Argentina fue el país que más judíos recibió en toda América del Sur. Los judíos que llegaron al Perú en su mayoría fueron de origen alemán, aunque no obedeció a una oleada inmigratoria sino más bien a viajes individuales por razones particulares. Esta es la razón de porque también llegaron al Perú judíos de Polonia, Inglaterra, Norteamérica, Rusia, Francia y Australia.

$22 \mathrm{El}$ acceso es un poco complicado. Solo pueden visitar el camposanto quienes acrediten algún vínculo familiar con las personas cuyos cuerpos reposan allí. 
Las primeras casas comerciales judías se remontan a 1852 y se dedicaron a la venta de artículos importados, sastrería y productos de pastelería. Muchos de ellos adquirieron una inusual reputación debido al desempeño de su trabajo.

Considerando el número creciente de judíos en el Perú, se organizaron clubes de acuerdo al origen de procedencia. De esta manera, surgió el «Club Inglés» (1857), «Club Alemán» (1857) y el «Club Germania». Su asociación entre sí dio origen a la conformación de una sola sociedad con inferencia en aspectos religiosos, ayuda mutua y sobre todo brindar las condiciones para enterrar a sus muertos de acuerdo a sus tradiciones y religión. Hasta esos años, los judíos eran enterrados en el Cementerio Británico de Bellavista.

En 1869 y luego de varias reuniones prolongadas, los residentes judíos eligieron un Directorio Provisional para crear una «Sociedad de Beneficencia Israelita», conformado por J. Herzberg (Presidente), A. Badt (Vicepresidente), A. Godinsky (Secretario) y F. Lowy (Tesorero).

De acuerdo con el estudio de Siederer León, esta sociedad se fundó de manera oficial en 1870 bajo el nombre de «Sociedad Hebrea de Beneficencia», la misma que fue reconocida tres años después. El nombre de esta institución no queda claro, pues en forma cotidiana se menciona «Sociedad de Beneficencia Israelita», «Sociedad Hebrea de Beneficencia», así como el de «Sociedad Israelita de Beneficencia». Sin embargo, todas estas nomenclaturas representan la misma institución.

Una de las primeras labores de este Directorio fue elaborar los estatutos de organización tomando en consideración diversos aspectos de la vida cotidiana, como: ofrecer ayuda, sufragar los gastos de entierro, impartir la educación y tradición judía, así como registrar los matrimonios y defunciones, etc.

La mejor descripción de los judíos en Lima antes de la guerra con Chile corresponde a Carlos Herzberg, el mismo que es citado por León Trahtemberg: 
Vivimos acá en la República del Perú, país en el cual la libertad de culto todavía no se ha decretado por una ley y cuya población es católica en su totalidad. Se tolera, sin embargo, a todas las sectas y religiones disidentes, los que efectúan sus servicios religiosos en sus casas. Residen acá alrededor de 20 familias judías, entre las que se cuentan de treinta a cuarenta jóvenes solteros. También encontramos entre los varones casados a algunos que están capacitados para realizar los servicios religiosos en caso de algún fallecimiento o para las fiestas de Rosh Hazaña y Yom Kipur. Desde hace un año reside en Lima también un «Mohle», y por lo tanto ya no es necesario enviar a nuestros hijos a Europa para que se les practique la circuncisión. Además, desde el año 1870 organizamos una «Sociedad de Beneficencia Israelita» con el fin de ayudar a nuestros correligionarios en caso de indigencia o de enfermedad y también para atender que se les entierre en caso de su fallecimiento. Hasta ahora los difuntos han sido sepultados en un cementerio cristiano, pero en estos momentos intentamos adquirir un terreno propio para que sirva como cementerio, para lo cual ya conseguimos el permiso correspondiente por parte del gobierno [...] La mayoría de los residentes judíos en el Perú son alemanes, pero también hay algunos polacos, franceses y de otras nacionalidades [...]. (León 1987: 52)

$\mathrm{Al}$ igual que otras instituciones públicas y privadas, esta Sociedad disminuyó en su accionar al momento de desencadenarse la guerra con Chile, aunque prestó cierta ayuda económica al gobierno peruano que nunca pudo recuperar debido a la derrota del ejército peruano. 


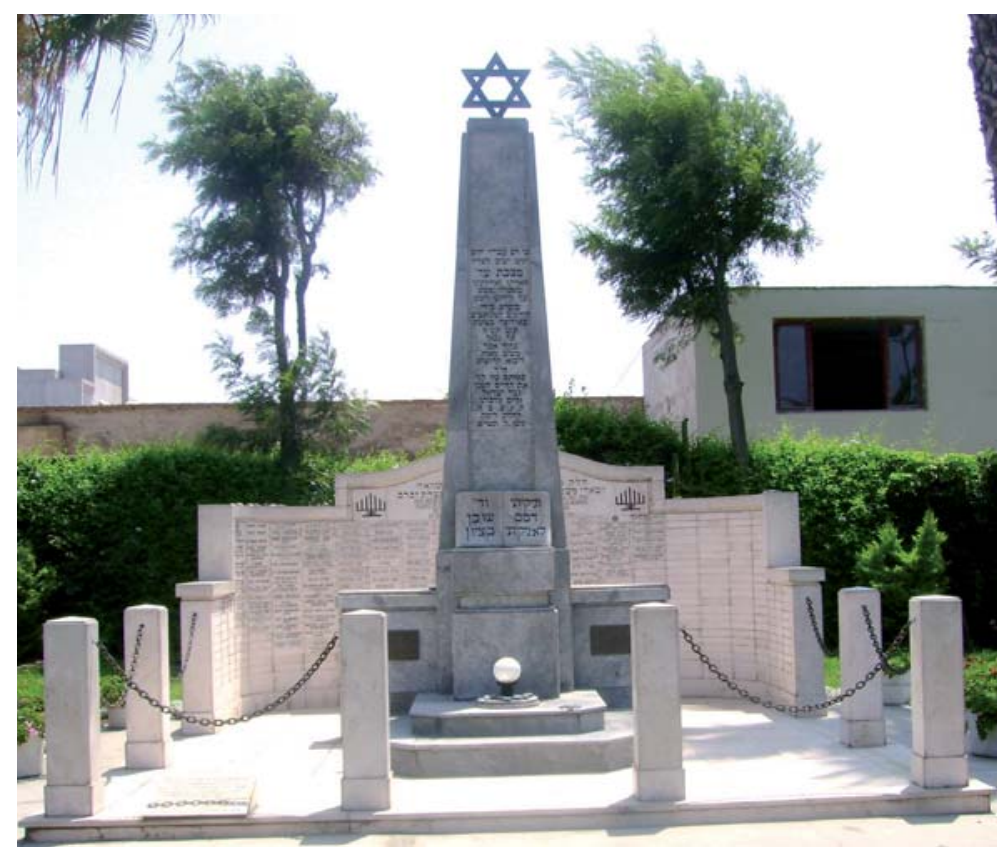

Obelisco coronado con estrella de David (Archivo Santiago Tácunan, 2005)

El origen del cementerio judío se remonta al establecimiento del Cementerio Británico de Bellavista en 1833. Pero es recién en 1869 que los judíos iniciaron los trámites para adquirir un terreno en donde construir un cementerio. Reunidos en la Beneficencia Hebrea, los judíos acordaron comprar un terreno en el valle de La Legua perteneciente a Enrique Meiggs, famoso constructor de ferrocarriles en Chile y el Perú.

El precio pactado por vara cuadrada fue de un centavo, precio muy cómodo para la época. Un primer contrato fue firmado en 1874 por 1593 varas cuadradas (15.93 soles), mientras que en 1875 se firmó otro contrato por 10684 varas cuadradas (106.84 soles). 
El camposanto fue inaugurado en 1875 con la instalación de una placa de mármol en la capilla, en donde se agradecía a quienes habían apoyado en su construcción. Una mención aparte tuvo Enrique Meiggs, a quien los judíos consideraban su amigo.

El primer occiso enterrado fue Mina Rosenberg, quien falleció en Lima el 7 de noviembre de 1875. Durante sus primeros años de funcionamiento, la Directiva del cementerio no tuvo mayores apuros económicos para sufragar el mantenimiento ni problemas administración. Sin embargo, a partir del siglo XX aparecen los primeros reclamos por la ampliación del cementerio y las áreas verdes adyacentes a la capilla. El problema subsistió durante varias décadas.

En 1922 y teniendo en cuenta este problema, un grupo de judíos reunidos en la Sociedad de Beneficencia Sefardi, propone a la Beneficencia Israelita asumir la administración del cementerio y aliviar las penurias económicas que afrontaba. La única condición fue utilizar el cementerio para enterrar a sus muertos. Otro grupo interesado en utilizar el lugar eran los judíos ashkenazim.

La propuesta fue rechazada y en sesión del 1 de diciembre de 1923, la Beneficencia Israelita acordó utilizar 40.6 libras peruanas para ampliar las instalaciones. Pero el mantenimiento continuó siendo un problema debido al reducido número de judíos de origen alemán que integraban la Beneficencia Israelita.

Ante esta situación, David Señor de Castro, fundador de la Sociedad Israelita, extendió una invitación a Samuel Eidelman, propulsor de la «Unión Israelita del Perú», para reunir fondos entre los ashkenazim con el fin de apoyar en algo las necesidades del cementerio. Gracias a su gestión se pudo reunir a un total de 70 ashkenazim que se comprometieron a apoyar en forma económica y desinteresada el sostenimiento del cementerio. 
A pesar de este apoyo la escasez de fondos continuó durante varios años, en donde se aprecia la incansable labor de la familia Alexander Rosenthal tratando de mantener la administración y orden de los archivos documentales. Esta labor fue continuada por los últimos fundadores de la Sociedad Israelita hasta 1938, año en que se decide que la "Unión Israelita» y la «Sociedad de Beneficencia Sefardí», asuman también la administración del cementerio. Esta fue una de las últimas actividades públicas de los miembros de la «Sociedad de Beneficencia Israelita» (León 1987: 52).

En la actualidad el cementerio judío no permite el ingreso a personas que no guarden directa relación con los difuntos, por lo que visitarlo resulta bastante difícil.

\section{EL CEMENTERIO GENERAL EL ÁNGEL}

A mediados del siglo XX, el Cementerio General El Ángel se convirtió en el espacio mortuorio de mayor extensión de Lima, aunque este título en la actualidad lo ostenta el cementerio municipal de Villa María del Triunfo, considerado como el más grande del Perú y uno de los más grandes del mundo.

La construcción de El Ángel fue a raíz de la saturación del Presbítero Maestro. Las obras ubicadas en el ex fundo Ancieta Alta se inició en junio de 1956 y culminó tres años después. La inauguración se realizó el 27 de junio de 1959 y contó con la asistencia del Presidente de la República, Manuel Prado Ugarteche. ${ }^{23}$

23 El año de su inauguración era Presidente de la Beneficencia Pública de Lima el Dr. Oswaldo Hercelles y las labores de inspección recayeron en el Dr. Raúl Porras Barrenechea. 


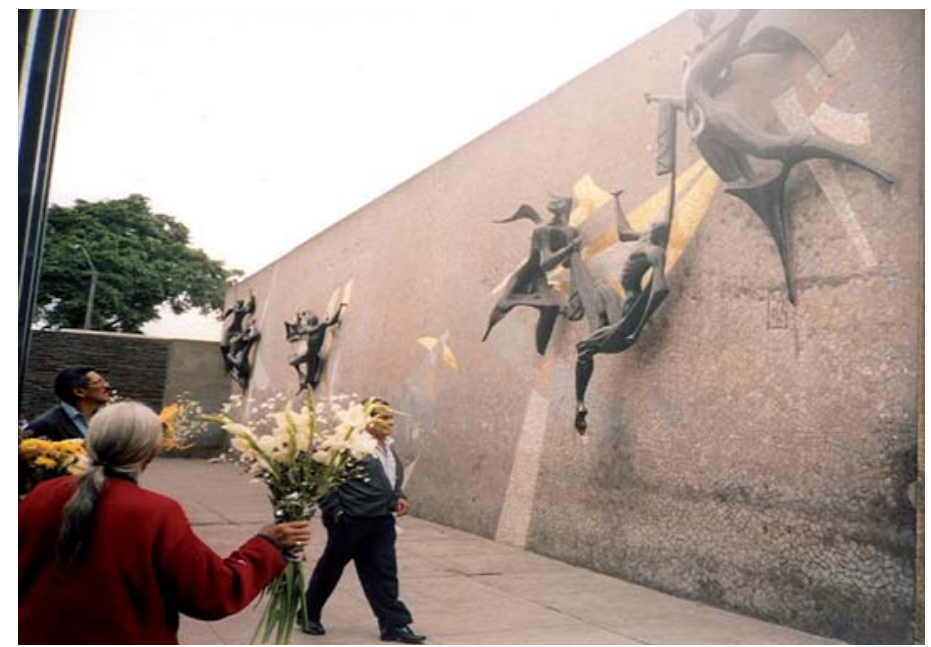

Conjunto escultórico «La Muerte» diseñado y construido por Fernando de Szyszlo (Archivo Santiago Tácunan, 2005)

El nombre del cementerio se debe a que fue construido muy cerca a la Plaza de El Ángel de la Resurrección, espacio público inaugurado en 1877 .

La decoración de la fachada estuvo a cargo de Joaquín Roca Rey y Fernando de Szyzslo, en donde destaca una serie de imágenes alegóricas a la muerte. 


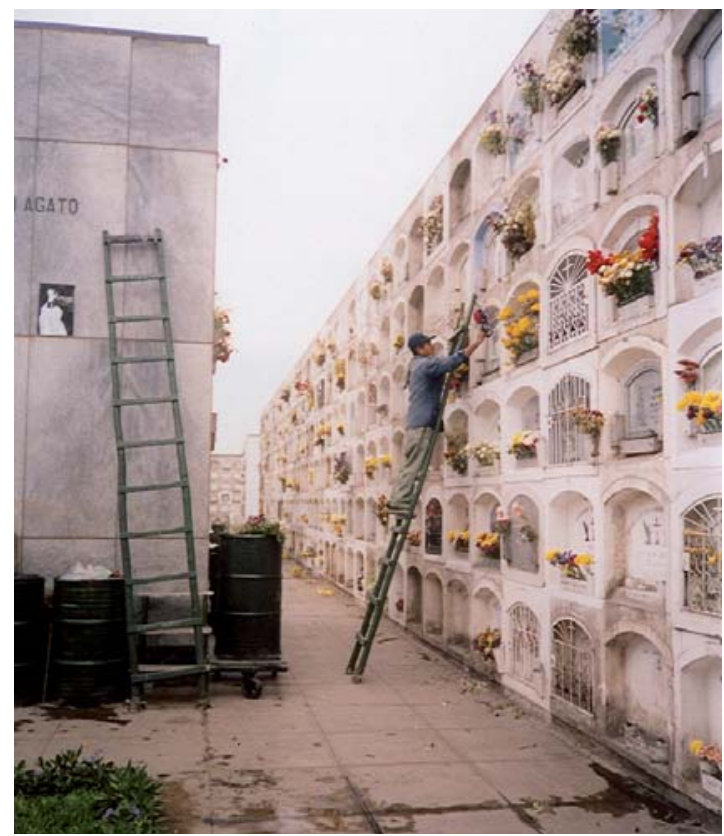

Vista general del Pabellón Santa Alma, 2007 (Archivo Santiago Tácunan, 2005)

Este cementerio dividido en numerosos cuarteles estuvo destinado para personas de bajos recursos económicos, aunque existen también una serie de nichos y mausoleos de reconocidos y populares personajes como: Luis Banchero Rossi, Akira Kato, Zenon Noriega, Chabuca Granda, Juan Velasco Alvarado, Augusto Ferrando, Lucha Reyes, Honorio Delgado, Pedro Huilca Tecse, Juan Uccelli Rainusso, Los Mártires de Uchuraccay, entre otros. ${ }^{24}$

En la actualidad también brinda el servicio de crematorio al público en general.

24 En julio del 2000, el Cementerio amplió sus servicios funerarios con la implementación de un moderno crematorio. 


\section{BIBLIOGRAFÍA}

Acosta, José de

1954 [1577] «De Procuranda Indorum salute o predicación del evangelio a los indios». Obras del Padre José de Acosta. Madrid: Biblioteca de Autores Españoles.

Aguirre Córdova, Diana Cecilia

2005 El Presbitero Maestro. Una aproximación histórica. Ponencia inédita presentada en requipa.

Aries, Phillipe

2000 La muerte en Occidente. Desde la edad media hasta nuestros días. Traducción de F. Carbajo y R. Perkin. Madrid: Taurus. Colección El Acantilado N. 18.

Barentzen G., Hilda

2006 El Panteón General de la Ciudad de Lima en el siglo XIX: Símbolo e Identidad. Letras, revista de la UNMSM. Lima.

Bardella, Gianfranco

1989 Un siglo en la vida económica del Perú (1889-1989). Lima: Banco de Crédito del Perú.

BöHM, Günther

1985 Judios en el Perú durante el siglo XX. Santiago de Chile: Universidad de Chile. 
Cabanillas, Virgilio Freddy

2003 «Un ars moriendi en San Marcos». Ukupacha N. 3-4, pp. 131-133.

Carcelen Reluz, Carlos Guillermo

1995 Las Doctrinas de Chaclla-Huarochiri. Siglos XVIy XVII. Organización $y$ desarrollo de las parroquias rurales en el Perú Colonial. Tesis de Licenciatura presentada en la Facultad de Ciencias Sociales de la Universidad Nacional Mayor de San Marcos. Lima.

Casalino, Carlota

2003 «La Muerte en Lima en el siglo XIX». Presbitero Maestro. Museo Cementerio de Lima. Lima: Comité Peruano del Consejo Internacional de Museos y ORALC y CIM, pp. 37-46.

Fuentes, Manuel Atanasio

1867 Lima. Apuntes históricos, descriptivos, estadisticas y de costumbres. Librería de Firmin Didot Hermanos Hijos y Ca ${ }^{a}$. París. Reproducción facsimilar (1985). Lima: Fondo del Libro-Banco Industrial del Perú.

Kubler, George A.

1946 "The Quechua in The Colonial World». Handbook of South American Indians, 2 Vols. Washington.

Lazo García, Carlos

1982 «Rebeliones populares en Huarochiri Colonial (1750-1821)». En: Huarochiri. Ocho mil años de historia. T. II. Municipalidad de Santa Eulalia de Acopaya. Huarochiri. 
León Trahtemberg, Siederer

1987 La Inmigración judía al Perú(1848-1948). Una historia documentada de la inmigración de los judios de habla alemana. Lima: Sociedad Judía de Beneficencia y Culto de 1870.

Lozada de Gamboa, Carmen

2000 Perú: Demarcación Territorial. Fondo Editorial del Congreso del Perú. Tomo I y II. Lima.

Mercurio Peruano

1964 [1791] Historia de la Hermandad y hospital de la Caridad. Lima: Edición Facsimilar Biblioteca Nacional del Perú. Tomo 1, pp. 9-16. Razón de los que han enterrado, muerto y curado en los hospitales de esta capital, desde el día de $1^{\circ}$ de diciembre de 1790 hasta 30 de noviembre de 1791, extraida de los libros que se llevan en ellos, y rectificada sobre el plan presentado por el Teniente de Policía al Excelentísimo Señor Virrey. IV tomos. Lima: Edición facsimilar Biblioteca Nacional del Perú.

Middendorf, Ernst Wilhelm

1973 (1893) Perú. Observaciones y estudios del pais y sus habitantes durante una permanencia de 25 años. Ed. UNMSM, III tomos. Lima.

LeOnardini, Nanda y Patricia Borda

1996 Diccionario iconográfico religioso peruano. Rubican Ediciones. Lima. 
Pacheco Vélez, César

1967 «Un testimonio ruso sobre el Perú en 1818». Revista Histórica, Órgano de la Academia Nacional de la Historia (Instituto Histórico del Perú), tomo XXX, pp. 355-399. Lima.

RAmón Joffre, Gabriel

2003 «La Metamorfosis de los espacios funerarios en la Lima colonial: en cementerio extramuros». En Presbitero Maestro. Museo Cementerio de Lima. Lima: Comité Peruano del Consejo Internacional de Museos y ORALC y CIM, pp. 29-35.

Tácunan Bonifacio, Santiago

1994 «El Juzgado de Aguas de Lima (Siglo XVII-XVIII). Su rol en la reconstrucción de la infraestructura sanitaria de Lima». Nueva Sintesis N. 1-2, pp. 119-129. Lima. 


\section{FUENTES DOCUMENTALES}

\section{University College of London}

1896 Memorándum. The Peruvian Corporation Ltd. 1896. London.

1930 The first fifty years of the Peruvian Corporation Ltd. 1890-1930. London.

\section{Archivo Histórico De La Municipalidad De Lima}

1808 Reglamento Provisional acordado por el Excelentísimo Señor Don José Fernando de Abascal y Sousa, Virrey y Capitán General del Perú, con el Ilustrísimo Señor Doctor Don Bartolomé María de las Heras, dignísimo Arzobispo de esta Santa Iglesia, para la apertura del Cementerio General de esta ciudad, conforme a lo ordenado por Su Majestad, en Reales Cédulas de 9 de diciembre de 1786, y 3 de abril de 787. Impreso en la Real Casa de Niños Expósitos. Fol. 1-27. Lima. Discurso que dirige a su Rey el Ilustrísimo Señor Doctor Don Bartolomé Maria de Heras, dignisimo Arzobispo de esta metrópoli con motivo de la apertura y bendición solemne del Cementerio General erigido en esta capital. Impreso en la Casa Real de Niños Expósitos. Fol. 1-22. Lima.

1808 Discurso que dirige a su Rey el Ilustrísimo Señor Doctor Don Bartolomé Maria de Heras, dignisimo Arzobispo de esta metrópoli con motivo de la apertura y bendición solemne del Cementerio General erigido en esta capital. Impreso en la Casa Real de Niños Expósitos, año de 1808.

1808 Reglamento Provisional acordado por el Excelentísimo Señor Don José Fernando de Abascal y Sousa, Virrey y Capitán General del Perú, con el Ilustrísimo Señor Doctor Don Bartolomé María de las Heras, dignisimo Arzobispo de esta Santa Iglesia, para la apertura del Cementerio General de esta ciudad, conforme a lo ordenado por Su Majestad, en Reales Cédulas de 9 de diciembre de 1786, y 3 de abril de 787. Lima. Impreso en la Real Casa de Niños Expósitos. Año de 1808. 
1807 Informe de Matías Maestro acerca de la falta de agua en el Cementerio General. Fol. 1-1v.

1817 Resultado de la administración del Cementerio de Lima desde su apertura en 1 de junio de 1808 hasta 31 de diciembre de 1817. Fol. 1.

1820 Reflexiones en apoyo de la incorporación del Cementerio General al Hospicio con benéfico de ambos establecimientos y del público. 26 de enero. Fol. 1-27v. Lima.

1820 Noticia de la erección del Cementerio General de Lima. 24 de enero. Fol. 1-1v. Lima.

\begin{tabular}{|c|c|c|}
\hline \multicolumn{3}{|c|}{ Archivo General de la Nación } \\
\hline \multicolumn{3}{|c|}{ Protocolos notariales } \\
\hline \multicolumn{3}{|c|}{ Escribano } \\
\hline \multicolumn{3}{|c|}{ Rodrigo Alonso Castillejo } \\
\hline \multicolumn{2}{|c|}{ Ignacio Ayllón Salazar } & 32 \\
\hline \multicolumn{2}{|c|}{ Pedro de Espino Alvarado } & 246 \\
\hline \multicolumn{3}{|c|}{ Superior Gobierno } \\
\hline Legajo & Cuad. & Año \\
\hline 30 & 959 & 1806 \\
\hline 26 & 470 & 1810 \\
\hline
\end{tabular}

Archivo de la Sociedad de Beneficencia Pública del Callao

1924-1938 Índice de cuarteles, nichos temporales

1848-1878 Socios de la Beneficencia

Año

1599-1602

1712 